binationen und unter Erhöhung der Dosis auf $50 \mathrm{mg} / \mathrm{kp}$ werden im Blut kurzzeitig Wirkstoffkonzentrationen von etwa $1 \mathrm{mg} / l$ erreicht (s. Abb. 1). Auch bei der Pour on-Applikation von Fenthion und Bayer 9017 am Schaf wurden bereits ähnliche ausgeprägte Abhängigkeiten der percutanen Resorption vom Lösungsmittel beobachtet ${ }^{6}$.

Wie aus Abb. 1 weiterhin beim Vergleich der Ergebnisse für Rind und Schaf hervorgeht, wird Dimethoat beim Schaf schwieriger resorbiert als beim Rind im Vergleich zum Trichlorphon.

Nach intramuskulärer Injektion von $50 \mathrm{mg} / \mathrm{kp} \mathrm{Di-}$ methoat am Schaf konnten wir im Blut Wirkstoffkonzentrationen von $3-4 \mathrm{mg} / l$ bis zu $8 \mathrm{~h}$ p. i. nachweisen; auch daran erkennt man die erschwerte percutane Resorption am Schaf.

13 W. Dedek u. H. SChWARZ, DWP 71013 vom 4. 11. 1968.
Versuche zur Beeinflussung der percutanen Resorption beim Schaf durch Zusatz von Tensiden zur Lösung der Insektizide erbrachten zunächst keine eindeutigen Ergebnisse; in den meisten Fällen konnte keine ausgeprägte Tensidwirkung festgestellt werden. Bei einer speziellen Gruppe von Tensiden zeigte sich jedoch ein interessanter Effekt; bereits in geringen Konzentrationen wird durch diese Substanzen die percutane Resorption von Dimethoat und Trichlorphon am Schaf nahezu vollständig unterdrückt ${ }^{13}$ (die maximalen Wirkstoffkonzentrationen im Blut liegen $<0,1 \mathrm{mg} / l)$. Damit könnten bei minimalen Rückstandsmengen im Körper Wirkstoffzubereitungen zur Ektoparasitenbekämpfung eingesetzt werden, die in der Zukunft im Hinblick auf die ständig geringer festgelegten Toleranzwerte für Insektizidrückstände von Bedeutung sein dürften.

\section{Absolute Configuration of Carboxyacetylquercinic Acid, Chemical Correlation of Carboxyacetylquercinic Acid with Lanosterol}

\author{
Hiroyuki Inouye and Katsuya Tokura * \\ Faculty of Pharmaceutial Siences, Kyoto University, \\ Sakyo-ku, Kyoto, Japan \\ (Z. Naturforsch. 25 b, 1194-1195 [1970]; eingegangen am 27. Juli 1970)
}

We have examined the triterpenoids of Trametes dickinsii Berk (Japanese name Hoorokutake) (Polyporaceae) and have isolated carboxyacetylquercinic acid and its methyl ester, along with polyporenic acid $\mathrm{C}$ and dehydrotumulosic acid of known structures and a new triterpenoid glucoside ${ }^{1}$.

ADAM et al. ${ }^{2}$ first isolated carboxyacetylquercinic acid from Daedalea quercina. By considering the NMR and mass spectra and on the basis of a few reactions together with a consideration of the known structures of the coexisting congeners, they assumed this acid to have the structure $\mathbf{1} \mathbf{c}$, which still lacks in confirmative chemical evidences.

This paper deals with the chemical correlation of that acid with lanosterol and the establishment of its stereochemistry. The acidic fraction of the $\mathrm{MeOH}$ extract of the fungus was subjected to silicagel column chromatography to afford carboxyacetylquercinic acid $1 \mathrm{a} * *\left(\mathrm{C}_{34} \mathrm{H}_{53} \mathrm{O}_{7}, \mathrm{mp} 221-224^{\circ},[\mathrm{a}]_{\mathrm{D}}+8.8^{\circ}\right)$ and carbomethoxyacetylquercinic acid $\mathbf{1} \mathbf{b} \quad\left({ }_{33} \mathrm{H}_{54} \mathrm{O}_{7}, \mathrm{mp}\right.$ $\left.165.5-167^{\circ},[\alpha]_{D}+0.7^{\circ}\right)$.

$\mathbf{1}$ a was methylated to $\mathbf{1} \mathbf{c}$, whose NMR spectrum ${ }^{2}$ showed a singlet of two protons at $\tau 6.59$, a singlet of three protons at $\tau 6.72$ and a signal of three protons centered at $\tau 6.32$ showing a fine splitting $(2 \mathrm{~Hz})$. This splitting indicated that $\mathbf{l} \mathbf{c}$ obtained here is a mixture of two rotamers, as was obtained by ADAM et al. However, $1 \mathbf{b}$ described above was methylated giving rise to $\mathbf{1} \mathbf{c}$, which showed only a three proton singlet at $\tau$ 6.33. Accordingly, the original carbomethoxyacetylquercinic acid $\mathbf{1} \mathbf{b}$, unlike $\mathbf{1} \mathbf{a}$, is stereochemically pure.
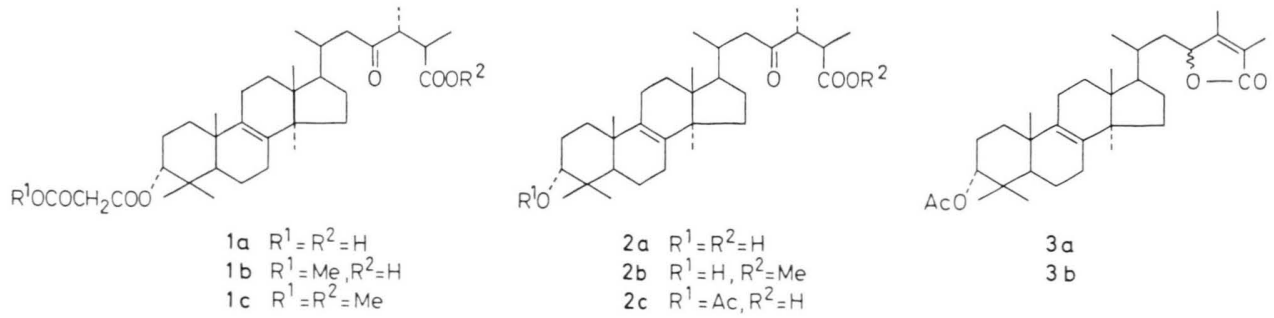

Reprints request to Prof. Dr. Hiroyuki InOuye, Faculty of Pharmaceutical Sciences, Kyoto University, Sakyo-ku, Kyoto, Japan.

* Present address: Shionogi Research Laboratory, Shionogi \& Co., Ltd., Fukushimaku, Osaka, Japan.

1 H. InOuye, K. TOKura, and T. Hayashi, Tetrahedron Letters [London], 1970, 2811.

2 H. K. Adam, T. A. Bryce, I. M. Cambell, N. J. McCorkindale, A. Gaudemer, R. Gmelin, and J. Polonsky, Tetrahydron Letters [London] 1967, 1461.

** Although our carboxyacetylquercinic acid has not yet been identified with the specimen of ADAM et al., the identity is evident from the comparison of the physical data. 


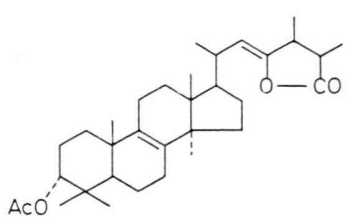

4

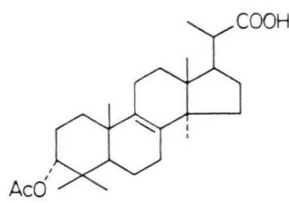

5<smiles>CC(=O)C(C)C1CCC2C3=CCC4C(=C3CCC21)CCCC4C</smiles>

6<smiles>CC(=O)OC1CCC2CC=C3C(=CCC4C3CCC4C(C)CCC=C(C)C)CCC21C</smiles>

7

$8 a R=H$
$8 b R=M e$

COOR<smiles>CCCC1(C)CC(C)(CC)C1CCC(=O)[O-]</smiles>

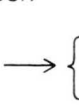<smiles>CCCC(C)C1CCC(C)(C)C1(C)C</smiles>

9<smiles>CCC(CC(=O)OC)CC(C)(C)O</smiles><smiles>CC(=O)CC1CCC2(C)CCC1(C)CC2(C)C</smiles>

Refluxing $\mathbf{1}$ a or $\mathbf{1}$ c with aqueous methanolic $\mathrm{KOH}$ yielded quercinic acid $2 \mathbf{a}\left(\mathrm{C}_{31} \mathrm{H}_{50} \mathrm{O}_{4}, \mathrm{mp} 217-221^{\circ}\right)$, which was further converted to the methyl ester $\mathbf{2} \mathbf{b}$, mp $137-138^{\circ}$ and the acetate $2 \mathbf{c}, \mathrm{mp} 243-244^{\circ}$. Enol lactonization of $\mathbf{2} \mathbf{c}$ with acetic anhydride and sodium acetate afforded two isomeric $\alpha, \beta$-unsaturated $\gamma$-lactones $3 \mathbf{a}, \mathrm{mp} 276-279^{\circ}$, and $\mathbf{3} \mathbf{b}$, mp 193-195 , and their double bond isomer $4, \mathrm{mp} 214-216^{\circ}$. The NMR spectrum of 4 showed a double doublet (J. 1.5, $10 \mathrm{~Hz}$ ) at $\tau 5.58$ (olefinic proton on C-22). Ozonolysis of 4 , followed by oxidative degradation with $\mathrm{J}$ o n e s' reagent, gave the carboxylic acid $5, \mathrm{mp} 271-273^{\circ}$. 5 was subjected to hydrolysis followed by methylation and subsequent oxidation with chromium trioxide to give the ketoester, which was converted into $6 \mathrm{C}_{28} \mathrm{H}_{44} \mathrm{O}_{4}$, mp $184-185^{\circ}$ by $\mathrm{NaBH}_{4}$ reduction and successive acetylation.

On the other hand lanosteryl acetate 7 was converted to 6 in the following way. Ozonolysis of 7 gave rise to the trinorcarboxylic acid $8 \mathbf{a}, \mathrm{mp} 208-212^{\circ}$, which was methylated to yield $8 \mathbf{b}, \mathrm{mp} 179-180^{\circ}$. $8 \mathbf{b}$ was subjected to $\mathrm{Grig} n$ a r d reaction with methyl-magnesium iodide and successive acetylation. However, as about one fifth of this reaction product was the $\Delta^{7,9(11)}$. diene compound, formed during the ozonolysis and $\mathrm{G} r$ ig $\mathrm{n}$ a rd reaction, it was hydrogenated over Pd-C affording the $\Delta^{8}$-monoene $9, \mathrm{mp} 172-173^{\circ}$, as the sole product. This was dehydrated with $\mathrm{POCl}_{3}$, successively ozonolysed and methylated to yield 10, mp $156-159^{\circ}$. The carbon chain of $\mathbf{1 0}$ was contracted by one carbon atom by the same degradative procedures as described above for $8 \mathbf{b}$ to give a compound, $\mathrm{mp} 184-185^{\circ}$, which was identified with 6 derived from the enol lactone 4. The negative Cot $\mathrm{t}$ o $\mathrm{n}$ effects observed in the CD curves of $1 \mathbf{a}, \mathbf{1} \mathbf{b}, \mathbf{1} \mathbf{c}, \mathbf{2} \mathbf{b}$ suggest an R-configuration at C-24. As described above, $\mathbf{1} \mathbf{a}$ is a mixture of C-25 epimers, so that the absolute structure of carboxyacetylquercinic acid was established. 